Zeszyty Naukowe Szkoły Głównej Gospodarstwa Wiejskiego

Ekonomika i Organizacja Gospodarki Żywnościowej nr 113, 2016: 89-103

Grażyna Koniorczyk

Wydział Zarządzania

Uniwersytet Ekonomiczny w Katowicach

\title{
Innowacje w zakresie interakcji z klientem i komunikacji marketingowej w handlu dyskontowym
}

\section{Wstęp}

Innowacyjność wydaje się być kluczowa dla utrzymania przewagi konkurencyjnej przez współczesne przedsiębiorstwa. Innowacje stanowią siłę napędową firm $\mathrm{z}$ różnych branż, w tym przedsiębiorstw handlowych realizujących niskokosztowy model biznesowy (z ang. low cost business model) bazujący na polityce trwale niskich cen (z ang. Every Day Low Prices). Sieci dyskontowe chcąc pozostać w strefie zysku na coraz trudniejszym rynku artykułów spożywczych, wdrażają innowacje marketingowe zwiększające wydajność operacyjna, a także zaangażowanie klientów i przywiązanie do marki. Strategia komunikacji marketingowej coraz częściej bazuje na interaktywnych relacjach oraz unikalnych doświadczeniach konsumentów. Mimo szerokiego wachlarza instrumentów oddziaływania rynkowego przedsiębiorstwom coraz trudniej budować skuteczne strategie komunikacji. Wynika to z nadmiaru informacji, niskiej lojalności względem marek oraz obniżenia skuteczności klasycznej reklamy. Firmy poszukują zatem nowych form przekazu i sposobów angażowania konsumentów w procesy komunikowania (się) z wykorzystaniem tradycyjnych i nowoczesnych mediów.

Celem opracowania jest rozpoznanie i scharakteryzowanie nowych środków i form komunikacji marketingowej, a także sposobów interakcji z klientem, stosowanych przez dyskontowe przedsiębiorstwa handlowe. Autorka posłużyła się metodą krytycznej analizy literatury krajowej i zagranicznej, a także metodą studiów przypadków. 


\section{Innowacje w zakresie marketingu i komunikacji marketingowej}

Innowacje i marketing stanowią dwa kluczowe czynniki tworzące bogactwo (dobrobyt) firmy i są najważniejszymi funkcjami biznesowymi generującymi nowych klientów [Cohen 2014]. W literaturze zwraca się uwagę głównie na innowacje techniczne (np. rozwój nowych produktów, nowe technologie usługowe), zdecydowanie mniej miejsca poświęcając innowacjom nietechnicznym (np. zarządczym), które w równie dużym stopniu wpływają na jakość oferty i wyniki rynkowe firmy (np. udział w rynku, sprzedaż, zyskowność). Innowacje marketingowe jako rodzaj innowacji zarządczych, oznaczają wdrożenie nowej koncepcji lub strategii marketingowej różniącej się od dotychczasowych stosowanych, podnoszących konkurencyjność i efektywność przedsiębiorstwa [Polder $\mathrm{i}$ in. 2010]. Innowacje w zakresie marketingu pozwalają m.in. na pełniejsze zaspokojenie potrzeb klienta, aktywowanie nowych rynków oraz korzystniejsze pozycjonowanie rynkowe produktu. Konsekwentnie prowadzą zatem do wzrostu sprzedaży i udziału w rynku oraz poprawy wyniku finansowego. Innowacje marketingowe zwiększają zdolność przedsiębiorstwa do reagowania na potrzeby rynku dzięki czemu osiaga ono wyższy poziom zadowolenia klientów w porównaniu z konkurencją [Baker i Sinkula 1999].

Zmiany w strategii marketingowej obejmują sferę produktu lub usługi (np. nowe wzornictwo, nowy projekt opakowania), dystrybucji (np. nowe metody dystrybucji lub lokowania rynkowego oferty, nowe kanały sprzedaży, nowe formy obsługi klienta), ceny (np. nowe formy dyskryminacji cenowej) i promocji (np. nowe metody i techniki promocji, nowe media) i służą przede wszystkim głębszej penetracji dotychczasowych lub nowych rynków. Innowacje w reklamie mogą dotyczyć nowych nośników, nowych form reklamy oraz nowych kanałów komunikacji [Pilarczyk 2011, s. 277]. Analizując innowacyjność działań komunikacyjnych, można zatem mówić o:

- nowych (nowoczesnych) mediach komunikacji marketingowej (np. Internet, telefony komórkowe);

- nowych (niestandardowych) formach komunikacji marketingowej (np. reklama wirusowa, blogi sponsorowane).

Uwzględniając walor nowości mediów i/lub form komunikacji marketingowej, można wyróżnić trzy ich kombinacje, a mianowicie:

1) niestandardowe formy komunikacji marketingowej w tradycyjnych mediach (np. product placement),

2) standardowe formy komunikacji marketingowej w nowoczesnych mediach (np. e-kupony), 
3) niestandardowe formy komunikacji marketingowej w nowoczesnych mediach (np. internetowe gry reklamowe).

W pierwszym przypadku wdrażane są nowe rozwiązania w konstruowaniu przekazów reklamowych emitowanych w tradycyjnych mediach, takich jak telewizja, radio, prasa, kino, billboardy. Stanowią one odpowiedź na spadek skuteczności i efektywności tradycyjnych mediów i komunikatów reklamowych. Przykładami niestandardowych rozwiązań są tzw. celebrity endorsement (wykorzystanie znanej osoby w komunikacie reklamowym), ambient marketing (niestandardowa i jednorazowa akcja marketingowa), product placement (lokowanie produktu w filmach i programach telewizyjnych), emisja kilkuminutowych filmów demonstrujących produkt w miejsce 30 -sekundowych spotów komercyjnych (tzw. branded entertainment).

$\mathrm{Na}$ standardową komunikację marketingową składają się narzędzia typu ATL (above the line) oraz BTL (below the line). Pierwszy grupa instrumentów wiąże się $\mathrm{z}$ działaniami komunikacyjni prowadzonymi w tradycyjnych mediach o charakterze masowym, natomiast druga $-\mathrm{z}$ działaniami ukierunkowanymi na konkretnego odbiorcę m.in. kolportaż materiałów reklamowych typu POS (point of sale), reklama przesyłana za pośrednictwem tradycyjnej poczty w formie listów adresowanych do konkretnej osoby. W literaturze wymienia się również reklamę TTL (through the line) stanowiąca efekt integracji ATL i BTL. ${ }^{1}$ Nowe media komunikacyjne zrodziły potrzebę dostosowania dotychczasowych form komunikacji do wymogów stawianych przez technologie internetowe i mobilne. Coraz popularniejsze stają się m.in. katalogi on-line, korespondencja e-mailowa (newslettery), reklama mobilna.

Najwyższy stopień innowacyjności cechuje ostatni przypadek, gdy rozwój nowoczesnych mediów przyczynia się do powstania absolutnie nowych form komunikacji marketingowej, takich jak blogi sponsorowane czy reklama wirusowa. Na znaczeniu zyskuje marketing mobilny umożliwiający firmom komunikowanie się i współpracowanie z użytkownikami za pośrednictwem dowolnego urządzenia mobilnego. Do narzędzi usprawniających komunikację z konsumentami można zaliczyć m.in. aplikacje i specjalne oprogramowanie na urządzenia dotykowe o treściach promocyjnych, SMS-y i MMS-y, fotokody (tzw. QR code) czy mobilne gry reklamowe ( $\mathrm{z}$ ang. mobile advergames).

Innowacje $\mathrm{w}$ sferze komunikacji z rynkiem można rozpatrywać pod kątem poziomu nowości i wyróżnić [Podręcznik OSLO... 2008]:

\footnotetext{
${ }^{1}$ Jedna z form reklamy stanowi punkt wyjścia dla kolejnej, np. reklama telewizyjna zachęca konsumenta do odwiedzenia sklepu (ATL); podczas wizyty w sklepie konsument otrzymuje kupon rabatowy lub los uprawniający do udziału w loterii (BTL) [Tymorek 2010, s. 71].
} 
- nowości dla firmy - znane i stosowane przez inne przedsiębiorstwa narzędzie i/lub środek komunikacji marketingowej są po raz pierwszy wdrożone przez dane przedsiębiorstwo;

- nowości dla rynku (lub sektora) - narzędzie i/lub środek komunikacji marketingowej są po raz pierwszy wdrożone przez dane przedsiębiorstwo na rynku lub w sektorze;

- nowości w skali światowej - narzędzie i/lub środek komunikacji marketingowej są po raz pierwszy wdrożone przez przedsiębiorstwo w skali całego świata.

\section{Uczestnictwo konsumentów w kreowaniu komunikacji marketingowej}

Współczesny sposób postrzegania roli klienta w procesie tworzenia wartości akcentowany jest przede wszystkim w koncepcjach: współtworzenia wartości autorstwa C.K. Prahalada i V. Ramaswamy'ego [2000, s. 79-87] oraz gospodarki opartej na logice usługowej (ang. service dominant logic, $S-D$ logic) opracowanej przez S.L. Vargo i R.F. Luscha [2004, s. 1-17]. W koncepcjach akcentujących centralną pozycję klienta odchodzi się od korporacyjnej logiki tworzenia wartości, a klienta uznaje się za integralną część systemu kreowania wartości mogącego aktywnie wpływać na tworzoną wspólnie z przedsiębiorstwem wartość. Oznacza to, że przedsiębiorstwo, aby współtworzyć wartość, musi wchodzić w relacje z klientem, który domaga się lepszego dostosowania oferty, a też sposobu komunikowania do indywidualnych oczekiwań. Ulega zmianie rola klienta, który z biernego odbiorcy komunikatu reklamowego staje się aktywnym jego współtwórcą. Komunikacja przeistacza się z komunikacji adresowanej do klientów w komunikację z udziałem klientów. Postuluje się odejście od prostej transmisji komunikatów na rzecz większego angażowaniem konsumenta w procesy komunikacji marketingowej. Konsumenci zyskują w ten sposób nowe możliwości zdobycia zindywidualizowanych doświadczeń.

Zgodnie z koncepcją ekonomii doświadczeń (ang. experience economy) przedstawioną przez B.J. Pine'a i J.H. Gilmore'a [1999], doświadczenia konsumentów kształtowane są w wyniku uczestnictwa, zarówno pasywnego (np. obserwacji wydarzenia marketingowego), jak i aktywnego. W ramach aktywnego uczestnictwa konsument sam kształtuje własne doświadczenia, (współ)tworząc wartość (np. podczas produkcji wideoklipu). Rolą przedsiębiorstwa jest wówczas przygotowanie odpowiedniego „kontekstu doświadczeń” oraz udostępnianie stosownych narzędzi (np. platformy, konfiguratora) umożliwiających konsumentowi samodzielne kreowanie własnych doświadczeń. Coraz częściej 
to konsumenci inicjują działania związane z projektowaniem i tworzeniem zindywidualizowanych doświadczeń w zakresie komunikacji z przedsiębiorstwem (np. blogi prowadzone przez konsumentów).

Konsumenci stanowią źródło innowacyjnych i kreatywnych pomysłów czy koncepcji reklamy (najczęściej komunikatu), ale też współuczestniczą w jej konstruowaniu (np. katalogów on-line), testowaniu czy upowszechnianiu. Autorskie filmy wideo użytkowników (tzw. user generated video) mogą być wyemitowane w mediach tradycyjnych (np. telewizji ogólnokrajowej), ale też upowszechnione na stronie firmowej, w mediach społecznościowych lub na specjalnych stronach (tzw. video hosting) przeznaczonych do dystrybucji wideoklipów [Thompson i Malaviva 2013, s. 33-47]. Angażowanie konsumenta w procesy współtworzenia podnosi autentyczność i wiarygodność przekazu reklamowego, niemniej oznacza także utratę pełnej kontroli nad procesem komunikacji marketingowej, tym samym zwiększa ryzyko braku spójności komunikatów odnoszących się do marki [Masiello, Marasco i Izzo 2013, s. 131-156].

Poniżej szerzej odniesiono się do dwóch innowacyjnych koncepcji zakładających aktywne uczestnictwo konsumentów w procesach komunikacji marketingowej w Internecie, a mianowicie Consumer Generated Media (CGM) oraz eWOM [Wang i Rodgers 2011, s. 212-213]. Pierwsza z nich związana jest $\mathrm{z}$ tworzeniem treści (tzw. content), natomiast druga $\mathrm{z}$ jej upowszechnieniem przez konsumentów i wśród konsumentów. Treści generowane przez konsumentów mogą przyjąć postać m.in. bloga, internetowej publikacji dźwiękowej lub filmowej (z ang. podcasts) czy zdjęcia wykonanego telefonem komórkowym. Treści sponsorowane przez przedsiębiorstwa na blogach bądź forach dyskusyjnych określa się terminem Consumer Generated Advertising (CGA). Składają się na niego zarówno reklamy graficzne, jak i sponsorowane teksty (np. recenzje, komentarze), zazwyczaj uzupełnione linkiem przekierowującym na stronę producenta lub sprzedawcy [Mutum i Wang 2011, s. 252].

$\mathrm{Z}$ kolei e-WOM (z ang. electronic word of mouth) odnosi się do pozytywnych lub negatywnych opinii wyrażonych za pośrednictwem Internetu przez potencjalnego, aktualnego lub byłego klienta na temat produktu lub firmy. Opinie te w znacznym stopniu wpływają na decyzje zakupowe innych konsumentów i uznawane są za bardziej wiarygodne niż deklaracje przedsiębiorstwa. E-WOM wykorzystywana w marketingu wirusowym (ang. viral marketing) ma za zadanie zainicjowanie sytuacji, w której potencjalni klienci będą sami między sobą rozpowszechniać informacje dotyczące produktów bądź firmy, ale też informacje ogólnie użyteczne (np. porady kulinarne) za darmo. By informacja zainteresowała użytkowników, musi przybrać wyjątkowo atrakcyjną treść lub formę, $\mathrm{np}$. interaktywnej gry, zabawnego zdjęcia lub wideoklipu, intrygującego sloganu reklamowego. Działania reklamowe mogą być zainicjowane przez przedsiębior- 
stwo, ale też samych konsumentów. Skuteczność reklamy wirusowej może być mierzona za pomocą mierników typowych dla tradycyjnej kampanii reklamowej (np. liczbą wyświetleń reklamy), ale też służących do pomiaru stopnia zaangażowania klienta (np. liczbą lajków, komentarzy) lub „dzielenia się” informacją (np. liczbą wideoklipów zamieszczonych przez użytkowników, rekomendacji, odpowiedzi (z ang. reposts) czy przekierowań na stronę z reklama) [Petrescu i Southeastern 2014, s. 78-97].

\section{Handel dyskontowy w Europie i Polsce}

Dyskonty są jednym z głównych kanałów sprzedaży produktów spożywczych dla konsumentów poszukujących oszczędności. Swoistymi identyfikatorami modelu biznesowego dyskontów są: trwale niskie ceny, wąski i płytki asortyment (500-1000 produktów), przewaga produktów opatrzonych marką własna, minimalistyczny wystrój i wyposażenie sklepów (o pow. $500-1500 \mathrm{~m}^{2}$ ), niewielki zakres usług sprzedażowych oraz wysoka wydajność operacyjna i dyscyplina kosztowa [Zentes i Rittinger 2009; Deleersnyder i in. 2007]. Dyskontowy handel detaliczny rozwija się przede wszystkim w Europie (tabela 1).

Tabela 1

Udział dyskontów spożywczych na europejskich rynkach krajowych w latach 2008 i 2013

\begin{tabular}{|l|c|c|c|}
\hline \multirow{2}{*}{ Kraj } & \multicolumn{2}{|c|}{ Udział w sprzedaży (\%) } & \multirow{2}{*}{$\begin{array}{c}\text { zmiana } \\
(\%)\end{array}$} \\
\cline { 2 - 3 } & 2008 & 2013 & 0.9 \\
\hline Niemcy & 33,3 & 34,2 & 8,4 \\
\hline Dania & 22,4 & 30,8 & $-1,8$ \\
\hline Austria & 27,8 & 26,0 & 12,2 \\
\hline Polska & 11,7 & 23,9 & 2,3 \\
\hline Holandia & 10,2 & 12,5 & 3,1 \\
\hline Szwajcaria & 7,7 & 10,8 & $-0,6$ \\
\hline Belgia & 10,8 & 10,2 & 1.2 \\
\hline Włochy & 8,0 & 9,2 & 5,9 \\
\hline Turcja & 3,0 & 8,9 & 0,6 \\
\hline Francja & 7,7 & 8,2 & 1.2 \\
\hline Hiszpania & 6,7 & 7,9 & 2,1 \\
\hline Grecja & 5,5 & 7,6 & 1,5 \\
\hline Finlandia & 3,8 & 5,3 & 1,5 \\
\hline Wielka Brytania & 3,4 & 4,8 & 0,8 \\
\hline Szwecja & 3,7 & 4,5 & \\
\hline
\end{tabular}

Uwaga: pominięto kraje z 0,1-proc. lub mniejszym udziałem w rynku.

Źródło: Euromonitor International. 
Kraje Europy Zachodniej zalicza się do głównych rynków „twardych” dyskontów ${ }^{2}$. Stopień rozwoju europejskiego rynku różni się w poszczególnych krajach. O nasyceniu (dojrzałości) rynku dyskontowego można mówić w odniesieniu do Niemiec i Austrii, podczas gdy we Francji czy Wielkiej Brytanii obserwuje się umiarkowany jego wzrost. Największa dynamika rozwoju tego kanału sprzedaży charakteryzuje Polskę i Danię. Udział dyskontów w Polsce wzrósł z 12 proc. 24 proc. w przeciagu pięciu lat. W alogicznym okresie w Danii dynamika wzrostu osiagnęła wartość 8,4 proc.

W Polsce dyskonty okazały się największym nowoczesnym kanałem sprzedaży generującym ponad 30 proc. przychodów detalistów spożywczych w 2013 roku (rysunek 1).

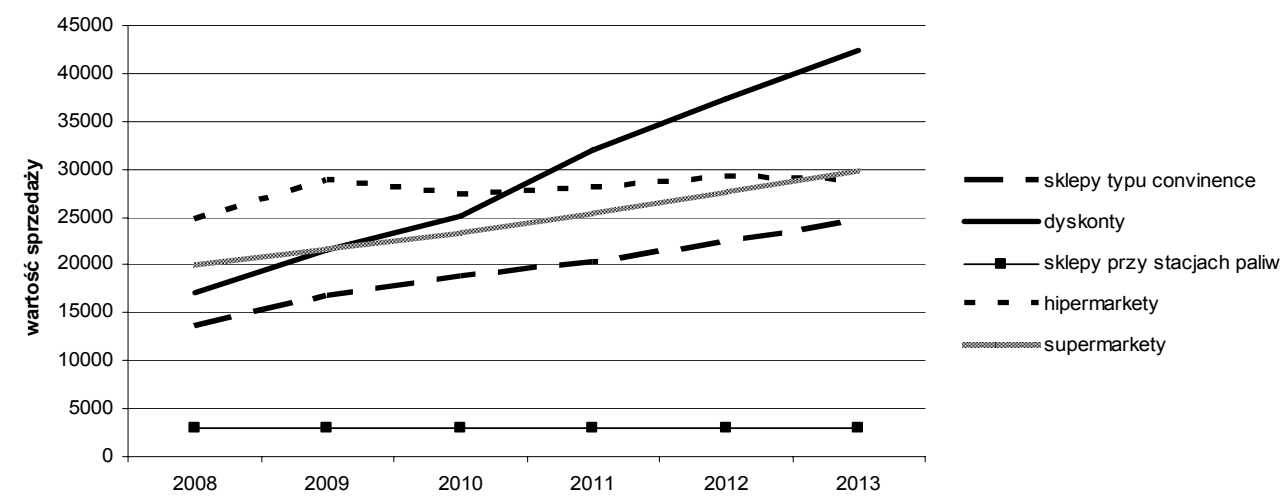

Rysunek 1

Wartość sprzedaży w nowoczesnych kanałach sprzedaży w Polsce w latach 2008-2013 (mln zł) Źródło: Na podstawie danych Euromonitor International.

Osiągając 13-proc. wzrost, dyskonty wyprzedziły sklepy typu convienence (10-proc.) i supermarkety (8-proc.). W tym samym czasie hipermarkety odnotowały 2-proc. spadek spowodowany przede wszystkim silną konkurencją ze strony dyskontów. W 2013 roku dyskonty wypracowały 42 354,8 mln zł (dla porównania drugie w kolejności supermarkety - 29 726,6 mln zł). Według ekspertów branżowych dyskonty wraz ze sklepami convienence są kanałami z najwyższym

\footnotetext{
${ }^{2}$ Powszechnie wyróżnia się dwa rodzaje sklepów dyskontowych: tzw. twarde dyskonty (z ang. hard discount, limited assortment discount), oraz ,miękkie dyskonty ( $\mathrm{z}$ ang. soft discount, discount supermarket). Wymienia się również supermarkety dyskontowe o poszerzonej grupie produktów (extended range discount) np. francuski Atac i hipermarkety dyskontowe (warehouse stores), np. niemiecki Kaufland [Domański 2005, s. 15]. Kryteriami różnicującymi dyskonty na „twarde” i „miękkie” są: szerokość asortymentu, wysokość kosztów operacyjnych, poziom cen i udział marek własnych.
} 
prognozowanym wskaźnikiem wzrostu sprzedaży do 2018 roku [Grocery Retailers in Poland... 2014].

W klasycznym modelu bazującym na niskich kosztach wydatki na reklamę i promocję uznawano za zbędne. Aktywność „,twardych” dyskontów w tym zakresie ograniczała się do wydawania gazetki handlowej, jej kolportażu w sklepach lub bezpośredniej dostawy do domów [Zentes i in 2011, s. 34]. Takie postępowanie miało przekonać nabywców, że w cenie produktów nie ukryto kosztów reklamy. Zmiany w otoczeniu zewnętrznym, głównie w obrębie rynków i sektora, spowodowały odejście dyskontów od „czystego” modelu niskokosztowego, czego wyrazem jest poszerzenie i różnicowanie asortymentu (np. wprowadzenie marek własnych typu premium), otwieranie nowych formatów sklepu nawiązujących do konceptu convenience, podwyższenie standardów w zakresie obsługi, sprzedaż wielokanałowa, ale też zintensyfikowanie działań reklamowych i wizerunkowych. Format dyskontów ewoluuje zatem w kierunku supermarketów, co wymaga wprowadzenia zmian w sposobie komunikacji z rynkiem.

\section{Cel i metody badawcze}

Celem opracowania jest rozpoznanie i scharakteryzowanie innowacyjnych środków i form reklamy, a także nowych sposobów interakcji z klientem, stosowanych przez dyskontowe przedsiębiorstwa handlowe. Wydaje się, że działania te ukierunkowane są na zmianę wizerunku współczesnych dyskontów, które chcą być postrzegane jako nowoczesne sklepy z bardzo dobrą ofertą asortymentową. Autorka posługując się metodą przypadków o charakterze opisowym (ilustracyjnym), szczegółowo odniosła się do niestandardowych form i nośników komunikatów marketingowych oraz sposobów angażowania klientów. Prezentowane przykłady zostały opracowane na podstawie informacji z krajowych i zagranicznych baz danych (m.in. GMID), prasy (m.in. wywiady z kadrą zarządzająca), raportów branżowych, oficjalnych dokumentów oraz materiałów internetowych.

W niniejszym opracowaniu poddano analizie formy i/lub nośniki reklamy stosowane przez trzy sieci dyskontowe, a mianowicie: Lidl, Aldi oraz Biedronkę (tabela 2). Należą one do grupy wiodących detalistów na rynkach krajowych. W 2014 roku sieć Lidl zajmowała pozycję lidera w 13 krajach w Europie, Aldi -7 [Kucharska i in. 2015, s. 48]. Biedronka pozostaje od wielu lat niekwestionowanym liderem w Polsce. W 2014 roku sieć posiadała ponad 2,5 tys. sklepów o łącznej pow. sprzedaży przekraczającej $1,5 \mathrm{mln} \mathrm{m}^{2}$, a jej obrót brutto wyniósł $8341 \mathrm{mln}^{\mathrm{euro}}{ }^{3}$

\footnotetext{
${ }^{3} \mathrm{~W}$ analogicznym roku Grupa Schwarz (Lidl, Kaufland) z liczbą 729 sklepów o łącznej powierzchni $1,2 \mathrm{mln} \mathrm{m}^{2}$ i obrotem brutto w wysokości $4450 \mathrm{mln}$ euro zajęła drugą pozycję. Top
} 
Tabela 2

Charakterystyka sieci dyskontowych

\begin{tabular}{|c|c|c|c|}
\hline Kryteria & Aldi & Lidl & Biedronka \\
\hline Właściciel & Grupa Aldi & Grupa Schwarz & Jeronimo Martins \\
\hline Kraj pochodzenia & Niemcy & Niemcy & Portugalia \\
\hline Rynki & $\begin{array}{c}17 \text { krajów (Europa, } \\
\text { Stany Zjednoczone, } \\
\text { Australia) }\end{array}$ & 24 kraje (Europa) & Polska \\
\hline Liczba sklepów* & 9762 & 9890 & 2393 \\
\hline Sprzedaż on linie & $\begin{array}{c}\text { tak } \\
\text { wybrane kategorie } \\
\text { produktów }\end{array}$ & $\begin{array}{c}\text { tak } \\
\text { wybrane kategorie } \\
\text { produktów }\end{array}$ & nie \\
\hline Strona www & $\begin{array}{c}\text { tak } \\
\text { (strony krajowe) }\end{array}$ & $\begin{array}{c}\text { tak } \\
\text { (strony krajowe) }\end{array}$ & tak \\
\hline Aplikacje mobile & tak & tak & tak \\
\hline Media społeczne & $\begin{array}{c}\text { Facebook, Twitter } \\
\text { YouTube, Pinteres } \\
\text { i i in. }\end{array}$ & $\begin{array}{c}\text { Facebook, Twitter, } \\
\text { YouTube, Instagram } \\
\text { i in. }\end{array}$ & YouTube \\
\hline \multicolumn{4}{|c|}{ Aktywność w serwisie społecznościowym Facebook } \\
\hline $\begin{array}{l}\text { Liczba fanów } \\
\text { (Facebook) }\end{array}$ & 1628073 & 10176453 & - \\
\hline $\begin{array}{l}\text { Zaangażowanie } \\
\text { klientów mierzone } \\
\text { liczbą interakcji**) }\end{array}$ & 2278377 & 4371592 & - \\
\hline $\begin{array}{l}\text { Troska o klienta } \\
\text { mierzona liczbą } \\
\text { odpowiedzi na } \\
\text { zapytania klientów }\end{array}$ & 5591 & 13670 & - \\
\hline
\end{tabular}

*Dane za 2013 rok. ** Łącznie: polubienia (tzw. likes), komentarze i opinie.

Źródło: Strony internetowe detalistów, http://www.socialbakers.com

O rosnącej randze komunikacji marketingowej w strategii dyskontów świadczy wzrost wydatków na reklamę. W pierwszym półroczu 2015 roku Lidl w Wielkiej Brytanii zwiększył wydatki na reklamę o 400 proc., wyprzedzając lidera rynku sieć Tesco. ${ }^{4}$ Lidl i Biedronka przodują w wydatkach na reklamę wśród sieci handlowych w Polsce. W 2014 roku Lidl przeznaczał na reklamę tygodniowo średnio 5-7,5 mln zł (według oficjalnych cenników stacji telewizyjnych). ${ }^{5} \mathrm{~W}$ tymże roku Lidl wydał ponad $370 \mathrm{mln}$ zł na ok. 110 tys. emisji reklam, zdobywając pozycję lidera wśród sieci handlowych, a Biedronka - oko-

10 detalistów $w$ Polsce. http://magazynhandel.pl/2015/09/21 /biedronka-niekwestionowanym-liderem 10.10.2015.

${ }^{4}$ www.marketingmagazine.co.uk z dn. 15.10.2015.

${ }^{5}$ www.dlahandlu z dn. 15.06.2015. 
ło $200 \mathrm{mln}$ zł. Aldi w pierwszej kolejności zwiększa wydatki na reklamę poza rynkiem niemieckim. W Wielkiej Brytanii budżet kampanii reklamowej Shop a Lidl Smarter ma wynieść 20 mln funtów ${ }^{6}$. Aldi po raz pierwszy uzyskał tytuł oficjalnego sponsora brytyjskiej reprezentacji na Igrzyska Olimpijskie w 2016 r., planując w związku z tym wydanie na działania reklamowe i wizerunkowe około $10 \mathrm{mln}$ funtów.

\section{Przykłady innowacyjnych form i środków reklamy dyskontów}

O kreatywności i inwencji dyskontów świadczą następujące przykłady działań w zakresie niestandardowej reklamy lub jej nośników:

- $\quad \mathrm{w}$ tradycyjnych mediach:

- nowe formy reklamy zwiększające obecność marki w telewizji, np. branded entertainment, product placement, celebrity endoresment,

- organizowanie nietypowych wydarzeń opartych na interakcji z klienta$\mathrm{mi}, \mathrm{np}$. otwieranie tymczasowych restauracji (tzw. pop-up restaurants) i sklepów (tzw. pop-up stores);

- w nowoczesnych mediach:

- internetowe gry reklamowe tworzone przez firmę,

- organizowanie internetowych i mobilnych kampanii/akcji reklamowych o intrygującej fabule, które prowokują konsumentów do jej upowszechniania.

Zwiększeniu skuteczności reklamy telewizyjnej mają pomóc programy telewizyjne zrealizowane w nietypowej konwencji. Oparty na formule talk show program kulinarny promujący produkty sieci Lidl w Polsce pn. Dorota, Karol $i$ goście jest tego typu zabiegiem marketingowym. Pięciominutowy program prowadzą znana dziennikarka i kucharz. W kanale Discovery Networks wyemitowano serię trzyminutowych 7 miniprogramów demonstrujących drogę jaką pokonują od dostawcy do sklepu wybrane produkty Lidl. Sieć wraz z irlandzką stacją telewizyjną RTE wyprodukowała sześcioodcinkowy teleturniej pn. Smak sukcesu (The taste of success). Uczestniczacy w programie lokalni producenci zgłaszali własne propozycje produktów (np. przepis na konfiturę, deser).

Lokowanie produktu przybiera różne formy, np. eksponowania logo detalisty (lub marki własnej). Ale też rozmowy na temat marki. Biedronka pojawia się

\footnotetext{
${ }^{6}$ www.biztok.pl/biznes/lidl z dn. 10.10.2015. www.thedrum.com/news/2015/06/11/lidl-taste-tests-public-real-reaction-brand-campaign $\mathrm{z}$ dn. 10.10.2015.
} 
w serialach (np. „Ojciec Mateusz”, „Klan”), Lidl w programie kulinarnym (np. „Ugotowani”). Jednak nadmierna ekspozycja marki może przynieść odwrotny skutek, o czym przekonała się sieć Biedronka. W związku ze zbyt nachalną reklamą marki w serialu „Klan” klienci złożyli oficjalny protest do Komisji Etyki TVP.

Dyskonty wykorzystują znane osoby, tzw. celebrytów, do reklamowania produktów. Dobór znanych osób zależy od atrakcyjności i wiarygodności ich wizerunku dla marki. Są to najczęściej znani kucharze, cukiernicy i sommalierzy, czyli osoby postrzegane jako eksperci w dziedzinie kulinariów. Ambasadorami sieci Lidl w Polsce są obecnie kucharz Karol Okrasa (jeszcze do niedawna również Pascal Brodnicki), cukiernik Paweł Małecki oraz sommalier Michal Jancik. W Wielkiej Brytanii świadomość żywieniową i umiejętności kulinarne Brytyjczyków rozwija szef kuchni Kevin Love, który w programach kulinarnych wykorzystuje produkty linii Deluxe. „Twarzy” użyczają dyskontom również wybitne osobowości ze świata filmu, rozrywki i sportu, np. aktor Daniel Olbrychski w kampanii promującej polskie produkty sieci Biedronka, dziennikarka Dorota Wellman w reklamach Lidla czy mistrz Europy w gimnastyce artystycznej Daniel Purvis w reklamach Aldi.

Dyskonty organizują niestandardowe akcje bądź kampanie reklamowe o charakterze kontekstowym, np. otwarcie tymczasowej restauracji (z ang. popup restaurants, temporary restaurants) lub sklepu (z ang. pop-up store, flash retailing). Lidl uruchomił w Szwecji restaurację pod nazwą DILL (anagram słowa LIDL) serwującą przez trzy tygodnie dania przyrządzone wyłącznie z produktów Lidla. Podobne restauracje z dobrym jakościowo menu otworzyła sieć Aldi w Londynie. Oba przedsięwzięcia miały przekonać konsumentów o tym, że wykwintny posiłek nie musi być drogi. W Polsce Biedronka serwowała ciepłe posiłki w tymczasowej kawiarni Cafe Biedronka otwartej na czas trwania Forum Ekonomicznego w Krynicy. Relatywnie nowym zjawiskiem w handlu są tymczasowe punkty sprzedaży detalicznej w wyjątkowych lokalizacjach o dużym natężeniu ruchu. Sklepy pop-up sieci Lidl otwarto na terenie festiwalu muzycznego „Przystanek Woodstock” w Kostrzynie nad Odrą oraz festiwalu muzyki elektronicznej „Tomorrowland” w Belgi. W Polsce, obok sklepu o konstrukcji namiotowej, zlokalizowano strefę rozrywki ,chill out” z barem kawowym oraz miejscem do przygotowania śniadań.

$\mathrm{Na}$ narodowych fan page'ach Lidl zorganizował sześciotygodniowy turniej piłkarzyków Lidl Fun Cup, w którym udział wzięło 8 mln fanów z 23 krajów. Specjalna aplikacja połączyła świat wirtualny i rzeczywisty. Nie opuszczając miejsca zamieszkania, gracz mógł rozegrać mecze z reprezentantami innych krajów posługując się specjalną aplikacją sterująca grą piłkarzyków. Na potrzeby gry w prawdziwej hali sportowej rozstawiono 50 stołów ze 100 zmechanizowa- 
nymi boiskami wyposażonymi w bandy reklamowe eksponujące 25 linii produktów. Ekspozycja reklamy zmieniała się losowo po każdym wirtualnym ruchu piłkarzyka. Mecze transmitowane za pomocą 300 kamer można było oglądać w czasie rzeczywistym. Każdy z graczy miał kontakt z reklamą Lidla średnio przez 84 sekundy. Ponad 40-godzinny materiał filmowy i zdjęciowy udostępniono przedstawicielom mediów na specjalnej platformie. W ciagu sześciu tygodniu liczba fanów na Facebooku wzrosła o 500 tys. osób. ${ }^{7}$

Interesującym przykładem marketingu wirusowego jest międzynarodowa kampania mobilna Valentine Kiss sieci Lidl. Objęła ona 24 kraje w Europie. Zakochane pary po pobraniu specjalnej aplikacji mobilnej ze strony korporacyjnej lub platformy Facebook, uwieczniały za pomocą kamery w smartfonie lub laptopie swój pocałunek. Link z adresem pobrania aplikacji szybko rozprzestrzenił się w Internecie. Zdjęcia całujących się par były sprawdzane przez ,wykrywacz pocałunku" wyposażony w system detekcji twarzy. Po pozytywnej weryfikacji para mogła wziąć udział w losowaniu nagród walentynkowych.

\section{Przykłady angażowania konsumentów w zakresie komunikacji marketingowej}

Uwzględnienie klientów w działaniach komunikacyjnych staje się coraz ważniejsze ze względu na wzrost częstotliwości i intensywności interakcji z nimi, które coraz częściej wykraczają poza sprzedaż. Dyskonty angażują klientów poprzez udostępnienie miejsca (przestrzeni) dla upowszechniania treści tworzonych przez konsumentów, np. blogi sponsorowane, fora dyskusyjne, wirtualne społeczności wokół marki, a także narzędzi wspierających konsumentów w tworzeniu treści (np. aplikacje mobilne). W tym miejscu można wspomnieć o kilku przedsięwzięciach dyskontów aktywizujących konsumentów. Sieć Aldi w Stanach Zjednoczonych prowadzi oficjalny blog Simply Smarter Living inspirujący użytkowników do poszukiwania oszczędności w prowadzeniu domu. Lidl podpisał umowę partnerską z jednym z największych brytyjskich portali dla rodziców Mumsnet, których użytkownicy poszukują i dzielą się poradami na temat rodzicielstwa. Operator zyskał nowe źródło informacji o potrzebach konsumentów, ale też sposobność dotarcia z ofertą produktową do nowego segmentu rynku. Sieć Aldi uruchomiła specjalną stronę (www.likealdi.co.ue) zawierającą krótkie firmy reklamowe zrealizowane przez konsumentów. Większość z nich stanowi reklama porównawcza produktów sieci Aldi z ich droższymi odpowiednikami innych producentów. Wokół marek dyskontowych tworzone są społeczności (np.

${ }^{7}$ www.mrm.de/showcase/lidl-fan-cup/ z dn. 10.10.2015. 
kuchniaLidla) umożliwiające konsumentom dzielenie się przepisami kulinarnymi i poradami dotyczącymi gotowania. Serwis Aldi Mamia Parent Club pozwala użytkownikom na testowanie i ocenę produktów dla dzieci, ale też konwersacje $\mathrm{z}$ innymi rodzicami na tematy związane $\mathrm{z}$ wychowaniem dzieci.

Nowym rodzajem budowania więzi z klientem są konkursy oferujące korzyści inne niż finansowe. Na podstawie zdjęć nadsyłanych przez konsumentów w ramach konkursu Aldi pn. Top Dog Model wybrano dwa psy, których wizerunki znalazły się na opakowaniach karmy dla zwierząt. Konkursy wykorzystujące kreatywność i wiedzę konsumentów polegają m.in. na poszukiwaniu oryginalnych pomysłów (np. na najlepszą recepturę ciasta wielkanocnego), ale też ich selekcji (np. wybranie wzorów nadruków dla limitowanej kolekcji torb zakupowych). Klienci mogą również decydować o formie i treści komunikatów (np. reklamy). Przykładem zaangażowania klientów w tworzenie promocji sprzedażowej jest akcja sieci Lidl w Holandii. Aplikacja Lidl likes umożliwiła użytkownikom serwisu Facebook wybór produktów, które powinny być objęte promocją w kolejnym tygodniu. Produkty z największa liczbą „lajków” pojawiały się na półkach sklepowych ze stosowną adnotacją. Aldi w Australii oferuje klientom uczestnictwo w rocznym programie testowania nowych produktów Aldi Testers Club. Od opinii testerów uzależniona jest decyzja o wprowadzeniu (lub też nie) konkretnego wariantu produktu na rynek. Komentarze i opinie uczestników są wykorzystane w materiałach reklamowych. Według podobnych reguł funkcjonuje serwis „testujemy.biedronka.pl”. Każdorazowo pięciuset testerów wypróbowuje nowe produkty, a także współtworzy ofertę sieci, decydując o wariancie produktu, który trafi do sprzedaży.

\section{Wnioski i podsumowanie}

Dyskonty spożywcze skutecznie zmieniają dotychczasowy wizerunek „tanich sklepów", wykorzystując w tym celu nowe formy i środki komunikacji marketingowej. $Z$ tym zamiarem prowadzą zintegrowaną strategię komunikacji z rynkiem z użyciem tradycyjnych i nowoczesnych mediów. W ramach strategii repozycjonowania wizerunku i budowania silnej marki dyskonty zwiększają częstotliwość i intensywność kontaktu z marką (np. nietypowe akcje reklamowe, niekonwencjonalne programy telewizyjne), inspirują i podnoszą świadomość konsumentów w zakresie gotowania (np. blogi kulinarne, znani kucharze $\mathrm{w}$ roli ambasadorów marki), a także zmniejszają dystans $\mathrm{w}$ relacjach $\mathrm{z}$ klientem. Przejawem większego angażowania konsumentów jest (współ)tworzenie lub/i upowszechnianie treści (opinii, komentarzy itp.) na temat firmy i jej oferty w mediach społecznych i Internecie. 


\section{Literatura}

BAKER W.E., SINKULA J.M., 1999: The synergistic effect of market orientation and learning orientation on organisational performance. Journal of Academy of Marketing Science, Vol. 27 (4).

COHEN W.A., 2014: Drucker o marketingu, Wydawnictwo Słowa i Myśli, Lublin.

DAY G.S.,1994: The capabilities of market-driven organization. Journal of Marketing, Vol. 58.

DELEERSNYDER B., DEKIMPE M.G., STEENKAMP J.B., KOLL O., 2007: Win-win strategies at discount stores, Journal of Retailing and Consumer Services, Vol. 14.

Grocery Retailers in Poland. Euromonitor International. March 2014 (data dostępu 10.10.2015)

KUCHARSKA B., KUCIA M., MACIEJEWSKI G., MALINOWSKA M., STOLECKA-MAKOWSKA A., 2015: The retail trade in Europe - diagnostic and future perspective. Wydawnictwo Uniwersytetu Ekonomicznego w Katowicach, Katowice.

KUMOR K., 2011: Spoleczna recepcja product placement [w:] K. KUBIAK (red.): Spoleczna recepcja Public Relations, Wyższa Szkoła Promocji, Warszawa.

MASIELLO B., MARASCO A., IZZO F., 2013: Co-creation in creative service: the role of client in advertising agencies' innovations, Mercati e Competitivita No 2.

MUTUM D., WANG Q., 2011: Consumer Generated Advertising in Blogs [w:] M.S. EASTIN, T. DAUGHERTY and N.M. BURNS (ed.): Handbook of Research on Digital Media and Advertising: User Generated Content Consumption. IGI Global.

PETRESCU M., SOUTHEASTERN N., 2014: Viral Advertising and the Implications of Social Media [in:] I. LEE (ed.): Integrating Social Media into Business Practice, Applications, Management, and Models, Advances in E-Business Research, IGI Global.

PILARCZYK B. 2011: Innowacje w komunikacji marketingowej. Zeszyty Naukowe Polskiego Towarzystwa Ekonomicznego, $\mathrm{Nr} 9$.

PINE B. J., GILMORE J.H., 1999: The experience economy: Work is the theatre and every business is a stage. HBS Press, Boston.

Podręcznik Oslo. Zasady gromadzenia i interpretacji danych dotyczacych innowacji, 2008, Wydanie trzecie. Ministerstwo Nauki i Szkolnictwa Wyższego, Warszawa.

POLDER M., LEEUWEN G.V., MOHNEN P., RAYMOND W., 2010: Product, process and organizational innovation: drivers, complementaritiy and productivity effects: UNUMERIT, Maastricht Economic and Social Research and Training Centre on Innovation and Technology.

PRAHALAD C.K., RAMASWAMY V., 2000: Co-opting customer competence, Harvard Business Review, Vol. 78 (1).

THOMPSON D.V., MALAVIVA P., 2013: Consumer-Generated Ads: Does Awareness of Advertising Co-Creation Help or Hurt Persuasion? Journal of Marketing, Vol. 77.

VARGO S.L., LUSCH R.F., 2004: Evolving to a new dominant logic for marketing, Journal of Marketing, Vol. 68 (1).

WANG Y., RODGERS S., 2011: Electronic Word of Mouth and Consumer and Generated Content: From Concept to Application [w:] M.S. EASTIN, T. DAUGHERTY and N.M. BURNS (ed.): Handbook of Research on Digital Media and Advertising: User Generated Content Consumption. IGI Global. 
ZENTES J., MORSCHETT D., SCHRAMM-KLEIN H., 2012: Strategic Retail Management. Gabler Verlg, Springer Fachmedien Wiesbaden GmbH.

ZENTES J., RITTINGER S., 2009: Retailing in Germany: Current Landscape and Future Trends, European Retail Research, Vol. 23, Issue I.

\title{
Ilnnovations in customer interactions and marketing communication in discount retail market
}

\begin{abstract}
The aim of the study is to identify and characterize innovative forms and means of marketing communication, as well as new ways of interactions implemented by discount retailers. The method of critical analysis of literature and case study research are applied. Discount networks effectively changed the image of "cheap stores" using new forms and means of marketing communication. The (re)positioning strategy and building a strong brand are connected with increasing frequency and intensity of contact with the brand, inspiring and educating consumers, as well as engaging them.
\end{abstract}

Key words: marketing communications, innovations, discounters, customer engagement

\section{Abstrakt}

Celem opracowania jest identyfikacja i charakterystyka innowacyjnych form i sposobów komunikacji marketingowej, a także sposobów interakcji stosowanych przez dyskonty. Autorka posłużyła się metodą krytycznej analizy literatury krajowej i zagranicznej, a także analizą przypadków (case study research). Badania pokazały, że sieci dyskontowe skutecznie zmieniają wizerunek rynkowy, wykorzystując w tym celu nowe formy i środki komunikacji marketingowej. $\mathrm{W}$ ramach strategii repozycjonowania wizerunku i budowania silnej marki dyskonty zwiększają częstotliwość i intensywność kontaktu z marką, inspirują i podnoszą świadomość konsumentów w zakresie gotowania, a także zmniejszają dystans w relacjach z klientem.

Słowa kluczowe: komunikacja marketingowa, innowacje, dyskonty, zaangażowanie klienta 